Original Article

Artigo Original

Congeta Bruniere Xavier Fadel ${ }^{1}$ Ana Paula Dassie-Leite ${ }^{2}$ Rosane Sampaio Santos ${ }^{1}$ Marcelo de Oliveira Rosa ${ }^{3}$ Jair Mendes Marques ${ }^{1}$

Keywords

Voice

Voice Quality

Acoustics

Speech Acoustics

Singing

Descritores

Voz

Qualidade da Voz

Acústica

Acústica da Fala

Canto

Correspondence address:

Congeta Bruniere Xavier Fadel

Rua Tomazina, 239, Ahú, Curitiba (PR),

Brasil, CEP: 80540-160.

E-mail: congetab@yahoo.com.br

Received: 08/26/2014

Accepted: 11/12/2014

\section{Acoustic characteristics of the metallic voice quality}

\section{Características acústicas da qualidade vocal metálica}

\begin{abstract}
Purpose: To characterize the fundamental frequency and the frequency of the formants F1, F2, F3, and F4 from vocal emissions of amateur singers with metallic voice quality. Methods: There were 60 amateur female singers aged between 18 and 60 years old; 30 women with metallic voice quality forming the study group (SG) and 30 women without such a vocal quality forming control group (CG). The sample was selected through voice screening confirmed by reviewers after reaching a consensus. Regarding data collection, sustained vowel emissions in usual tone and at two predetermined frequencies, by which the values of $\mathrm{F}_{0}$ and frequency of the formants F1, F2, F3, and F4 were obtained, were recorded and analyzed. Results: Comparing the emissions in usual tone, no difference for $\mathrm{F}_{0}$ was found, but the values of the formants F2, F3, and F4 were higher in the SG. In the preestablished tones, there was a difference between the two groups in the formants F3 and F4 for both tones. Conclusion: It is possible to characterize metallic voice quality as a normal fundamental frequency, with increasing frequency of the F2 formant, and values of frequencies of formants F2, F3, and F4 higher when compared to the CG.
\end{abstract}

\section{RESUMO}

Objetivo: Caracterizar a frequência fundamental $\left(\mathrm{F}_{0}\right)$ e frequência de formantes F1, F2, F3 e F4 das emissões vocais de cantoras amadoras com qualidade vocal metálica. Métodos: Participaram da pesquisa 60 cantoras amadoras, com idades entre 18 e 60 anos, sendo 30 mulheres de qualidade vocal metálica integrando o grupo estudo (GE) e 30 mulheres sem essa qualidade vocal compondo o grupo controle (GC). A amostra foi selecionada através de triagem vocal confirmada por avaliadores, em consenso. Para a coleta de dados, foram gravadas e analisadas emissões de vogal sustentada em tom habitual e em duas frequências pré-determinadas, pelas quais extraíram-se os valores de $\mathrm{F}_{0}$ e frequência de formantes F1, F2, F3 e F4. Resultados: Quanto à comparação das emissões em tom habitual, não houve diferença para $\mathrm{F}_{0}$, mas os valores dos formantes $\mathrm{F} 2$, F3 e F4 foram maiores no GE. Nas tonalidades pré-estabelecidas, verificou-se diferença entre os dois grupos nos formantes F3 e F4, em ambos os tons. Conclusão: Foi possível caracterizar a qualidade de voz metálica como de voz de frequência fundamental normal, com frequência de formante F2 aumentado, e valores de frequências de formantes F2, F3 e F4 maiores quando comparados ao GC.

Study carried out at in the Graduate Program in Communication Disorders, Universidade Tuiutí do Paraná UTP - Curitiba (PR), Brazil.

(1) Graduate Program in Communication Disorders, Universidade Tuiutí do Paraná - UTP - Curitiba (PR), Brazil. (2) Speech Language Pathology and Audiology Department, Universidade Estadual do Centro-Oeste - UNICENTROIrati (PR), Brazil.

(3) Department of Electrical Engineering, Universidade Tecnológica Federal do Paraná - UTFPR - Curitiba (PR), Brazil.

Financial support: Conselho Nacional de Desenvolvimento Científico e Tecnológico - CNPq.

Conflict of interests: nothing to declare. 


\section{INTRODUCTION}

The metallic voice quality is described by literature as being strident, thin, and unpleasant ${ }^{(1)}$; it is also associated with the vocal resonance pattern of pharyngeal focus ${ }^{(2)}$. Its emission is related to vocal tract contraction by adjustments in pharyngeal constriction and articulators, laryngeal elevation, adductor tension ${ }^{(3)}$, velar lowering, aryepiglottic constriction, and lateral constriction ${ }^{(2)}$.

Voice metallization is considered to be an efficient voice projection resource by singers and actors, and it is generally used in specific singing styles, like American country music ${ }^{(3)}$. However, because this vocal production involves hyperfunctional adjustments in the vocal tract ${ }^{(2)}$, and is being seen as acute and annoying ${ }^{(3)}$, it is also considered to be a voice resonance disorder outside the artistic context ${ }^{(1)}$.

Glottic and supraglottic adjustments combined to the anatomic characteristics of the individual are responsible for the characterization of voice quality ${ }^{(4,5)}$. This combination directly impacts the measurements of the formant frequencies (FF), in which F1 and F2 (lower formants) are sensitive regarding the position of the lips and the tongue in the oral cavities; the upper formants (F3 and F4) are related to the total length of the vocal tract ${ }^{(6,7)}$.

The importance of this type of approach to a singing teacher is based on the knowledge regarding the acoustic phenomena that occur in the vocal tract; therefore, this professional can develop a more objective technical reasoning and apply scientific principles to the pedagogical practice.

The objective of this study was to characterize the fundamental frequency and formant frequencies of F1, F2, F3, and F4, of vocal emissions of amateur female singers with metallic voice quality.

\section{METHODS}

This was an observational, analytical, and cross-sectional study. The sample comprised 60 amateur female singers, aged between 18 and 60 years old; 30 women with metallic voice quality comprising the study group (SG) (mean age 32.6 years old), and 30 women without such a voice quality composing the control group (CG) (mean age 34.2 years). The project was approved by the ethics committee of Hospital de Clínicas of Universidade Federal do Paraná (UFPR), number 154.350.

The sample was selected by a perceptual-auditory voice screening test (which included voice samples of sustained emission of the vowel $/ \varepsilon /$, continuous speech, and singing) conducted by a researcher who had 13-year experience as a singing teacher. She identified 30 metallic and 30 non-metallic voices. The voice samples were confirmed by three judges - two singing teachers with the same academic formation in music and one speech-language pathologist who was an expert in voice having an average of eight years' experience in their respective fields. They all clearly shared the definition of the expression "metallic voice" and had previous knowledge regarding the production and the perceptual-auditory identification of the researched vocal pattern.
By consensus, the judges confirmed which would be the sample voices considered to be metallic or non-metallic. For that procedure, samples of metallic voice quality were those presenting focus on pharyngeal resonance, making the judge uncomfortable due to the characteristics that are compatible with strident voices.

After the confirmation, the collection stage started, which consisted of recorded samples of the vocal emission of the vowel $/ \varepsilon /$, in habitual tone (HT) and in two predetermined tones (frequencies) - A3 $(220.0 \mathrm{~Hz})$ and C5 $(523.2 \mathrm{~Hz})$. Emissions were recorded with the software $\mathrm{SONAR}^{\circledR}$, version 8.0.2, with unidirectional microphone Shure ${ }^{\circledR}$, model SM58, placed at $45^{\circ}$ and $4 \mathrm{~cm}$ away from the singer's mouth. For the predetermined tones, the auditory reference before every emission was the digital keyboard from the software SPEECHPITCH, version 1.1.

Samples were imported to the software PRAAT, version 5.3.42, to perform the acoustic analysis. From the emissions in $\mathrm{HT}$, values of fundamental frequency were extracted $\left(\mathrm{F}_{0}\right)$ as well as the measurements of the formant frequencies F1, F2, $\mathrm{F} 3$, and $\mathrm{F} 4$; for the emissions in predetermined tones, values of F1, F2, F3, and F4 were extracted. For the analysis of these frequencies (in $\mathrm{Hz}$ ), only the six central seconds of each emission were used as selection criteria for the sound records, so the initial and final seconds were not considered, and the most stable fragments were extracted.

Data were statistically analyzed with the parametric Student's $t$-test, with significance level of $0.05(5 \%)$.

\section{RESULTS}

The intragroup comparison for HT showed that there were no differences for vocal parameter $\mathrm{F}_{0}$, but values for F2, F3, and F4 were higher in the SG (Table 1).

In the preestablished tones, a difference was observed between both groups for F3 and F4, in both tones (Table 2).

\section{DISCUSSION}

In the musical field, it is possible to observe that singing teachers are not unanimous regarding the use of terminology to describe different vocal qualities and their respective vocal tract adjustments; there, they use some names based only on auditory sensations and body vibrations ${ }^{(8)}$. Therefore, the association between the acoustic analysis and the perceptual-auditory analysis in the description/identification of the vocal quality can be described as a complementary resource for this practice.

In this study, the $\mathrm{F}_{0}$ values obtained for the female singers in both groups were similar to the reference values ${ }^{(9,10)}$, so it is possible to state that the metallic voice quality cannot be considered to be the voice pattern of high $\mathrm{F}_{0}$. However, the acute pitch sensation attributed to it is a result of the increasing frequencies and amplitudes of the formants ${ }^{(2)}$.

Regarding FF values, except for F1, all the formants in HT were higher for metallic voices. It is possible to relate this feature to the shortening adjustment of the vocal tract, that is, a 
Table 1. Comparison of the study and control groups for the variables $F_{0}, F 1, F 2, F 3$, and F4, in the emission of the vowel /E/ in habitual tone

\begin{tabular}{|c|c|c|c|c|c|}
\hline \multirow{2}{*}{ Variables } & \multicolumn{2}{|c|}{ Mean $(\mathrm{Hz})$} & \multicolumn{2}{|c|}{ Standard deviation } & \multirow{2}{*}{$\mathrm{p}$-value } \\
\hline & $S G(n=30)$ & $C G(n=30)$ & $S G(n=30)$ & $C G(n=30)$ & \\
\hline $\mathrm{F}_{0}$ & 212.35 & 210.49 & 25.71 & 19.56 & 0.7543 \\
\hline $\mathrm{F} 1$ & 615.42 & 609.01 & 72.86 & 52.18 & 0.6969 \\
\hline $\mathrm{F} 2$ & $2,175.89$ & $2,043.10$ & 145.42 & 197.83 & $0.0044^{*}$ \\
\hline F3 & $2,976.63$ & $2,731.48$ & 160.46 & 177.85 & $0.0000^{*}$ \\
\hline $\mathrm{F} 4$ & $4,407.52$ & $3,842.04$ & 218.13 & 314.82 & $0.0000^{*}$ \\
\hline
\end{tabular}

*Statistically significant values $(\mathrm{p} \leq 0.05)$ - Student's $t$-test

Caption: $S G$ = study group; $C G=$ control group; $F_{0}=$ fundamental frequency; $F=$ formant

Table 2. Comparison between the study and control groups for the variables F1, F2, F3, and F4, in the emission of the vowel /E/ for tones A3 and C5

\begin{tabular}{|c|c|c|c|c|c|}
\hline \multirow{2}{*}{ Variables } & \multicolumn{2}{|c|}{ Mean $(\mathrm{Hz})$} & \multicolumn{2}{|c|}{ Standard deviation } & \multirow{2}{*}{$\mathrm{p}$-value } \\
\hline & $S G(n=30)$ & $\mathrm{GC}(\mathrm{n}=30)$ & $S G(n=30)$ & $C G(n=30)$ & \\
\hline \multicolumn{6}{|l|}{ La 2} \\
\hline $\mathrm{F} 1$ & 605.00 & 620.04 & 76.22 & 45.60 & 0.3577 \\
\hline $\mathrm{F} 2$ & $2,117.17$ & $2,069.73$ & 171.43 & 187.97 & 0.3113 \\
\hline F3 & $2,972.23$ & $2,839.76$ & 175.54 & 244.76 & $0.0192^{\prime}$ \\
\hline $\mathrm{F} 4$ & $4,337.19$ & $4,142.15$ & 229.32 & 405.28 & 0.0254 \\
\hline \multicolumn{6}{|l|}{ Do 4} \\
\hline $\mathrm{F} 1$ & 771.91 & 712.14 & 134.97 & 136.90 & 0.0939 \\
\hline $\mathrm{F} 2$ & $1,501.16$ & $1,543.46$ & 351.20 & 319.71 & 0.6275 \\
\hline F3 & $2,697.04$ & $2,519.94$ & 252.42 & 274.51 & $0.0118^{*}$ \\
\hline $\mathrm{F} 4$ & $3,932.86$ & $3,612.50$ & 382.70 & 353.95 & 0.0014 \\
\hline
\end{tabular}

*Statistically significant values $(p \leq 0.05)$ - Student's $t$-test

Caption: $\mathrm{SG}=$ study group; $\mathrm{CG}=$ control group; $\mathrm{F}=$ formant; $\mathrm{SD}=$ standard deviation

shorter vocal tract would lead to higher FFs when compared to longer vocal tracts ${ }^{(5)}$. In terms of physiology, this vocal tract shortening would result in laryngeal elevation and hypertonicity of pharyngeal constrictor muscles, and these adjustments are associated with the production of metallic voice ${ }^{(1,2)}$.

Among these values, the F2 of the SG was above the reference value, which was $2,062 \mathrm{~Hz}^{(11)}$. This increase in $\mathrm{F} 2$ was related to the metallic voice production in a study that investigated the physiological adjustments related to it ${ }^{(2)}$. It is known that this formant is variable according to the placement of the tongue in the oral cavity, especially concerning the changes in its body and its placement in the anteroposterior direction ${ }^{(5,7)}$. Possibly, the muscle adjustments that led to this increasing frequency were a result of anteriorization and elevation of the tongue dorsum, similarly to the movement that takes place in the production of the vowel /i/. This tongue movement, besides the adjustments of lip stretching in a smile, is used for singing in order to look for voice metallization, and has been reported in literature as an adjustment that is present in this voice quality ${ }^{(3)}$. However, for that hypothesis to be confirmed, it would be necessary to perform complementary radiological/imaging tests.

In the emissions of predetermined tones, only F3 and F4 presented higher values for this voice quality. These formants can change in relation to the dimension of the vocal tract cavity, and their reduction would lead to increased frequencies ${ }^{(7,12)}$. In that case, the adjustments in the vocal tract applied by the SG during the emission of deep and acute tones possibly led to smaller dimensions of the vocal tract when compared to the CG.

\section{CONCLUSION}

From the vocal acoustic assessment, it is possible to conclude that amateur female singers with metallic voice quality present $\mathrm{F}_{0}$ within normality patterns. However, they present increased frequency values of formants F2, $\mathrm{F} 3$, and F4 in relation to the amateur female singers with non-metallic voice quality. The F2 formant seems to be mostly related to the metallic voice quality, because the mean values presented by the SG are higher than those indicated in the literature.

\section{ACKNOWLEDGMENTS}

We acknowledge the grant (number 158639/2012-0) provided by Conselho Nacional de Desenvolvimento Científico e Tecnológico (CNPq) for conducting this study.

*CBX was responsible for the study's project, and data collection, and tabulation, and manuscript elaboration; APDL supervised data analysis, and contributed with manuscript elaboration; RSS was responsible for general supervision of the study; MOR was responsible for supervision of the execution, and contributed with data analysis; JMM was responsible for data analysis.

\section{REFERENCES}

1. Boone DIR, McFarlane SC. A voz e a terapia vocal. $5^{\text {a }}$ edição. Porto Alegre: Artes Médicas; 1994. 
2. Hanayama EM, Camargo ZA, Tsuji DH, Pinho SMR. Metallic voice: physiological and acoustic features. J Voice. 2009;23(1):62-70.

3. Pinho SMR. Fundamentos em Fonoaudiologia. Rio de Janeiro: Guanabara Koogan; 1998.

4. Laver J. Principles of phonetics. New York: Cambridge University Press; 1994.

5. Camardo ZA, Madureira S. Dimensões perceptivas das alterações de qualidade vocal e suas correlações aos planos da acústica e da fisiologia. DELTA. 2009;25(2):285-317.

6. Kent RD. Vocal tract acoustics. J Voice. 1993;7(2):97-117.

7. Lindblom BE, Sundberg JE. Acoustical consequences of lip, tongue, jaw, and larynx movement. J Acoust Soc Am. 1971;50(4):1166-79.
8. Pacheco COLC, Marçal M, Pinho SMR. Registro e cobertura: arte e ciência no canto. Rev CEFAC. 2004;6(4):429-35.

9. Santos CC, Mituuti CT, Berretin-Felix G, Teles LCS. Características da fonetografia em mulheres com equilíbrio dentofacial. Rev Soc Bras Fonoaudiol. 2010;15(4):584-8.

10. Felippe ACN, Grillo MHMM, Grechi TH. Normatização de medidas acústicas para vozes normais. Rev Bras Otorrinolaringol. 2006;72(5):659-64.

11. Monteiro MC. Uma análise computadorizada espectrográfica dos formantes das vogais orais do Português Brasileiro falado em São Paulo [monografia]. São Paulo: Universidade Federal de São Paulo; 1995.

12. Sundberg J. Articulatory interpretation of the "singing formant". J Acoust Soc Am. 1974;55(4):838-44. 